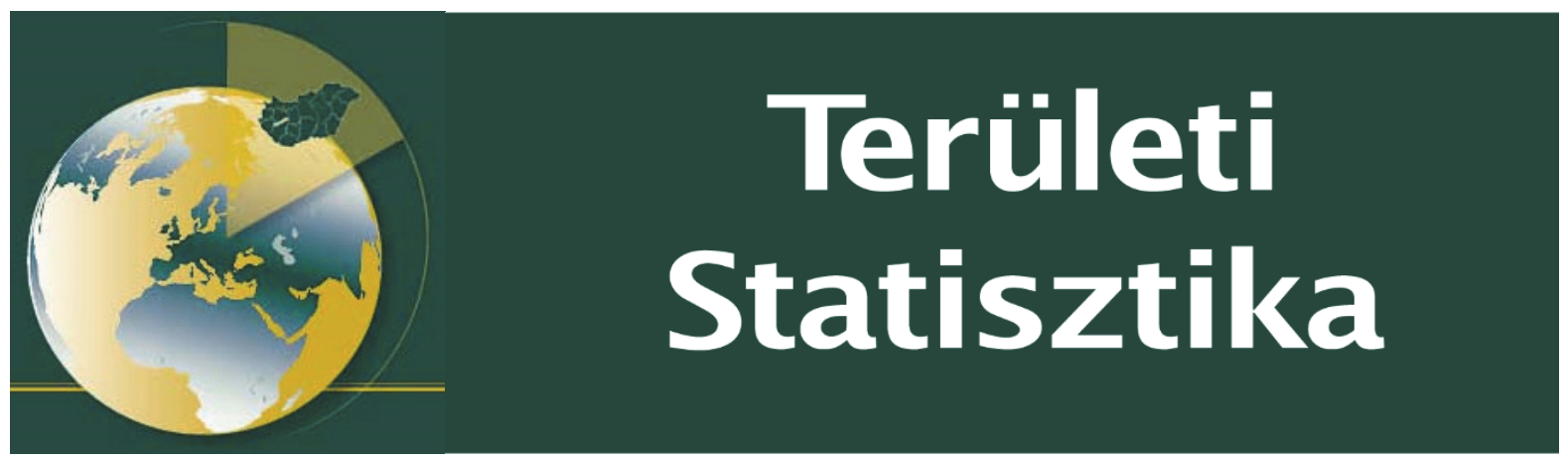

Közzététel: 2018. december 19.

A tanulmány címe:

Az önkormányzati rendszer átalakításának okai és az adósságkonszolidáció Szerzők:

Hegedűs Szilárd Nemzeti Közszolgálati Egyetem, Közpénzügyi Kutatóintézet,

E-mail: hegedus.szilard@uni-bge.hu

Novoszáth Péter Nemzeti Közszolgálati Egyetem, Közpénzügyi Kutatóintézet,

E-mail: Novoszath.Peter@uni-nke.hu

https://doi.org/10.15196/TS580603

Az alábbi feltételek érvényesek minden, a Központi Statisztikai Hivatal (a továbbiakban: KSH) Területi Statisztika c. folyóiratában (a továbbiakban: Folyóirat) megjelenö tanulmányra. Felhasználó a tanulmány, vagy annak részei felhasználásával egyidejüleg tudomásul veszi a jelen dokumentumban foglalt felhasználási feltételeket, és azokat magára nézve kötelezönek fogadja el. Tudomásul veszi, hogy a jelen feltételek megszegéséből eredő valamennyi kárért felelősséggel tartozik.

1) A jogszabályi tartalom kivételével a tanulmányok a szerzői jogról szóló 1999. évi LXXVI. törvény (Szjt.) szerint szerzői műnek minősülnek. A szerzői jog jogosultja a KSH.

2) A KSH földrajzi és időbeli korlátozás nélküli, nem kizárólagos, nem átadható, térítésmentes felhasználási jogot biztosít a Felhasználó részére a tanulmány vonatkozásában.

3) A felhasználási jog keretében a Felhasználó jogosult a tanulmány:

a) oktatási és kutatási célú felhasználására (nyilvánosságra hozatalára és továbbítására a

4. pontban foglalt kivétellel) a Folyóirat és a szerző(k) feltüntetésével;

b) tartalmáról összefoglaló készítésére az írott és az elektronikus médiában a Folyóirat

és a szerző(k) feltüntetésével;

c) részletének idézésére - az átvevő mű jellege és célja által indokolt terjedelemben és az eredetihez híven - a forrás, valamint az ott megjelölt szerző(k) megnevezésével.

4) A Felhasználó nem jogosult a tanulmány továbbértékesítésére, haszonszerzési célú felhasználására. Ez a korlátozás nem érinti a tanulmány felhasználásával előállított, de az Szjt. szerint önálló szerzői műnek minősülő mű ilyen célú felhasználását.

5) A tanulmány átdolgozása, újra publikálása tilos.

6) A 3. a)-c.) pontban foglaltak alapján a Folyóiratot és a szerző(ke)t az alábbiak szerint kell feltüntetni:

„Forrás: Területi Statisztika c. folyóirat 58. évfolyam 6. számában megjelent, Hegedüs Szilárd - Novoszáth Péter által irt Azönkormányzati rendszer átalakitásának okai és az adósságkonszolidáció c. tanulmány"

7) A Folyóiratban megjelenő tanulmányok kutatói véleményeket tükröznek, amelyek nem esnek szükségképpen egybe a KSH, vagy a szerzők által képviselt intézmények hivatalos álláspontjával. 


\title{
Az önkormányzati rendszer átalakításának okai és az adósságkonszolidáció
}

\section{Transformation of the Local Government and Debt Consolidation}

\author{
Hegedüs Szilárd A magyar önkormányzati rendszer a 1990-es in- \\ Nemzeti Közszolgálati duló időszakában igyekezett a kor legmodernebb \\ Egyetem, Közpénzügyi jellemzőit alapul venni, ám a modell folyamatos \\ Kutatóintézet, Budapesti változásával egyre inkább a múködésképtelenség \\ Gazdasági Egyetem, Pénzügyi és \\ Számviteli Kar \\ E-mail: \\ hegedus.szilard@uni-bge.hu \\ Novoszáth Péter \\ Nemzeti Közszolgálati \\ Egyetem, Közpénzügyi \\ Kutatóintézet \\ E-mail: \\ Novoszath.Peter@uni-nke.hu \\ szélére sodródott. A tanulmány célja, hogy be- \\ mutassa az önkormányzati rendszerben 2011-tôl \\ végbe ment szabályozásváltozásokat, a gazdálko- \\ dás jellemző nehézségeit, az eladósodás fóbb \\ okait, valamint a megvalósított adósságkonszoli- \\ dációt és ennek hatásait az önkormányzatok mú- \\ ködésére. \\ Kulcsszavak: \\ adósságkonszolidáció, \\ önkormányzati rendszer, \\ területfejlesztés, \\ városfejlesztés \\ In the early 1990s, the Hungarian local govern- \\ ment system has built on the most modern char- \\ acteristics of the era, but with the continuous \\ change of the model, it was increasingly drifting \\ to the edge of ineffectiveness. The purpose of \\ this study is to introduce the changes in the local \\ Keywords: \\ debt consolidation, \\ local government system, \\ regional development, \\ urban development \\ government system since 2011 along with the \\ typical difficulties of the management. The main \\ causes of indebtedness as well as the realised \\ debt consolidation and its effects on the func- \\ tioning of local governments are also presented.
}

Beküldve: 2018. március 1.

Elfogadva: 2018. szeptember 10.

Területi Statisztika, 2018, 58(6): 595-609; DOI: 10.15196/TS580603 


\section{Bevezetés}

Az önkormányzati alrendszer reformját több tényező is indokolta, amely a drasztikusan növekvő működési és felhalmozási hiányból, valamint a devizaadósságból adódóan egyre inkább megnehezítette a költségvetés által előirányzott hiányés adósságcélok teljesülését, illetve nagymértékú pénzügyi kockázatokat indukált. Az önkormányzati adósságállomány 2006-tól kezdve halmozódott fel, amelynek megoldási lehetôségét a Kormány az adósság átvállalásában látta. A nem szokványos lépésen túlmenően számos, a múködést alapvetően befolyásoló intézkedés született, új törvények formájában, amelyek hosszú távú kihatásait is számba vesszük.

\section{Az önkormányzati rendszer megújításának okai}

Már az 1990-es évek elejétől megkezdődött az önkormányzati alrendszer hiányának növekedése, amely az államháztartás egészében a decentralizált hiány kialakulását jelentette. A kormányzat folyamatosan adta le az önkormányzatok részére a korábban általa ellátott közfeladatokat, ám a forrásbiztosítás e feladatok ellátásához elmaradt. Ez az államháztartáson belül a hiány „eltolódását”, decentralizálódását váltotta ki, noha a központi költségvetés deficitje is emelkedett (Lentner 2016), majd a 2000-es évektől az önkormányzati szektor hiánya nagyságrendekkel nőtt.

2007 és 2010 között a helyi önkormányzatok adósságállománya jelentős mértékben, 491 milliárd forintról 1247 milliárd forintra emelkedett. Az adósság megugrásának okai közül ki kell emelni az állami források csökkenését, a térségi ellátást nyújtó intézmények átvételi kötelezettségéből adódó többletterheket, a gazdasági világválságot, illetve az európai uniós támogatásokkal ösztönzött fejlesztések önerőigényét. Mindez az önkormányzatok részéről nagyfokú alkalmazkodást, a külső források bevonását és a belső tartalékok feltárását igényelte. A megyei és a megyei jogú városi önkormányzatok 95\%-a bocsátott ki devizaalapú kötvényt 2007-2008-ban. A kötvénykibocsátásból befolyó bevételt részben korábbi előnytelen hitelek kiváltására és részben múködési hiány finanszírozására használták fel, de közel felét tartalékolták. Ez utóbbi hozamából származó kamatbevétel hozzájárult a múködőképesség fenntartásához. Az önkormányzatok eladósodásának egyik jellegzetessége volt, hogy kezdetben azt nem a fejlesztési hiány, hanem a későbbi fejlesztések finanszírozása és egyfajta pénzügyi tartalék képzése indokolta. Ennek megfelelően ezt a forrást csak a felvételt követő években, 2009-ben és fơként 2010-ben használták fel az önkormányzatok. Ennek a pénznek a segítségével nemcsak a beruházások saját forrását teremtették elő, hanem egyúttal az alrendszer és az államháztartás hiányának a növekedéséhez is hozzájárultak. Mindez azonban nem azt jelenti, hogy a 2010-es deficitcél elvetését maga az önkormányzati hitelfelvétel okozta volna. Sokkal inkább arról volt szó, hogy a központi tervezés során a Kormány annak ellenére alulbecsülte

Területi Statisztika, 2018, 58(6): 595-609; DOI: 10.15196/TS580603 
a tartalékfelhasználást, hogy az előre látható volt, miközben a helyi bevételek válság miatti kiesésével kapcsolatban is túl derúlátóak voltak az előrejelzések (ÁSZ 2011).

Az Állami Számvevőszék (ÁSZ) összességében a 19 megyei és a 23 megyei jogú városi önkormányzat 2007 és 2010 közötti pénzügyi helyzetének helyszíni ellenőrzésének tapasztalatai alapján szükségesnek itélte és megfontolásra javasolta a Kormány részére a pénzügyi egyensúly megteremtését, fenntartását segítő központi támogatások szigorú követelmények támasztásával történő nyújtását. Továbbá nem teljesítésük számonkérését, az önkormányzati felelősség erőteljes érvényesítését szolgáló szabályok megalkotását, valamint olyan állami pénzügyi konstrukció létrehozását, amely segíti az önkormányzatok fizetési kötelezettségei és a képződő forrásai közötti összhang rövid, illetve hosszú távú megteremtését.

Az Alaptörvény 31. cikk (3) bekezdése alapján a helyi önkormányzatokról szóló szabályozást sarkalatos törvény (Magyarország helyi önkormányzatairól szóló 2011. évi CLXXXIX. törvény) határozza meg. E törvény célja az önkormányzati rendszer átfogó megújítása volt.

1. táblázat

\section{Az új szabályozás problémái és megoldásai}

The problems of the new regulation and their solutions

\begin{tabular}{l|l}
\hline \multicolumn{1}{c|}{ Problémák } & \multicolumn{1}{c}{ Megoldások } \\
\hline $\begin{array}{l}\text { Túlzott feladatátadásból adódó } \\
\text { konfliktusok }\end{array}$ & $\begin{array}{l}\text { Állami és önkormányzati feladatok úiraszabályozása, } \\
\text { nagyobb állami szerepvállalás, differenciált feladatátadás }\end{array}$ \\
\hline $\begin{array}{l}\text { Önkormányzati feladatellátás alacsony } \\
\text { hatékonysága }\end{array}$ & $\begin{array}{l}\text { Közös önkormányzati hivatal, szabad társulási } \\
\text { rendszer }\end{array}$ \\
\hline Törvényességi ellenőrzés hiánya & Törvényességi felügyelet létrehozása \\
\hline $\begin{array}{l}\text { Nem követhető és nem átlátható } \\
\text { információk az önkormányzati } \\
\text { gazdálkodásról }\end{array}$ & $\begin{array}{l}\text { 2011. évi CXCV. törvény (Áht) szabályainak módosítása } \\
\text { (költségvetési rendelet megalkotása, tervezés, gazdálkodás, } \\
\text { beszámolás szabályai, számlavezetési, zárszámadási szabályok) }\end{array}$ \\
\hline $\begin{array}{l}\text { Kötelező feladatokhoz rendelt köz- } \\
\text { ponti forrásból származó normatívák } \\
\text { csökkenése }\end{array}$ & Feladatfinanszírozási rendszer \\
\hline $\begin{array}{l}\text { Szabályozatlan hitelfelvétel, kötvényki- } \\
\text { bocsátás }\end{array}$ & $\begin{array}{l}\text { Kötelezettségvállalás engedélyhez kötése (2011. évi CXCIV. } \\
\text { Stabilitási törvény) }\end{array}$ \\
\hline Eladósodottság & $\begin{array}{l}\text { Adósságkonszolidáció (2012., 2013. és 2014. évi } \\
\text { költségvetési törvények) }\end{array}$ \\
\hline Magas önerő miatt elmaradó fejlesztések & EU Önerő Alap létrehozása önkormányzatok számára \\
\hline
\end{tabular}

Forrás: Holczreiter et al. (2015).

Az Alaptörvényben adott jogalkotási felhatalmazás alapján a helyi önkormányzati rendszert a meglévő értékek megőrzésével és több új elem beillesztésével újítják meg, megőrizve a demokratikus jogállam alapelveinek a helyi hatalomgyakorlásban is érvényesülő szabályait. Alapvető cél, hogy a választópolgároknak a helyi önkor-

Területi Statisztika, 2018, 58(6): 595-609; DOI: 10.15196/TS580603 
mányzáshoz való joga változatlanul és hiánytalanul érvényesüljön, ugyanakkor az önkormányzati szervezet és múködés átalakítása segítse elő a közigazgatási szolgáltatások színvonalának emelését. Általános célként fogalmazták meg egy olyan modern, költségtakarékos, feladatorientált önkormányzati rendszer kiépítését, amely lehetőséget biztosít a demokratikus és hatékony múködésre, ugyanakkor - a választópolgárok önkormányzáshoz való kollektív jogait érvényre juttató és védendô módon - szigorúbb (felügyeleti jellegû) kereteket szab az önkormányzati autonómiának, és átalakítja az összeférhetetlenség szabályait is.

\section{Az állami és az önkormányzati feladatok újraszabályozása}

The re-regulation of state and local government tasks

\begin{tabular}{|c|c|c|}
\hline Államigazgatási feladatok & Köznevelés & Egészségügy \\
\hline $\begin{array}{l}\text { 2013. január 1-jétől a járási } \\
\text { hivatalok bevezetésével az } \\
\text { államigazgatási feladatok elinté- } \\
\text { zésének új szervezeti és eljárási } \\
\text { rendje. Ide került: például: } \\
\text { okmányiroda, gyámhivatal, épí- } \\
\text { tésügyi hivatal (építésfelügyeleti } \\
\text { hatósági, meghatározott építés- } \\
\text { ügyi hatósági feladatok), földhi- } \\
\text { vatal, munkaügyi kirendeltség. }\end{array}$ & $\begin{array}{l}\text { 2013. január 1-jétől az önkor- } \\
\text { mányzatok köznevelési feladatait } \\
\text { az állam vette át. Fő szabályként } \\
\text { a } 3 \text { ezer fö feletti önkormányzat } \\
\text { gondoskodik az intézményfenn- } \\
\text { tartó központ által fenntartott } \\
\text { intézmény feladatainak ellátását } \\
\text { szolgáló vagyon működtetéséről. }\end{array}$ & $\begin{array}{l}\text { A fekvőbeteg-szakellátás } \\
\text { állami feladat 2012-től. }\end{array}$ \\
\hline $\begin{array}{l}\text { Általános építésügyi hatósági } \\
\text { feladatok ellátása önkormányza- } \\
\text { ti feladat. }\end{array}$ & $\begin{array}{l}\text { Bölcsődei és óvodai feladatok } \\
\text { ellátása helyi szinten. }\end{array}$ & $\begin{array}{l}\text { Az alapellátás és járóbeteg- } \\
\text { szakellátás önkormányzati } \\
\text { feladat maradt. }\end{array}$ \\
\hline
\end{tabular}

Forrás: Holczreiter et al. (2015).

Magyarországon minden települést megillet az önkormányzás joga. A kérdés két évtizede főként az, mely feladatokat lássa el az állam és milyen feladatok maradjanak az önkormányzatoknál. Az Országgyúlés, a Magyarország helyi önkormányzatairól szóló 2011. évi CLXXXIX. törvény megalkotója a „feladatfinanszírozás” mellett döntött, ami annyit jelent, hogy az önkormányzatok a jövőben nem vállalhatnak el olyan feladatot, amit nem tudnak finanszírozni. A törvény tiltja, hogy 2013-tól múködési költségekre vegyen fel hitelt egy település, a kölcsönfelvételre vagy más kötelezettségvállalásra kormányzati hozzájárulás szükséges (Alaptörvény 34. cikk (5) bekezdés). Ezzel kapcsolatban azonban megemlítendő, hogy néhány pénzügyi instrumentumhoz (például likvidhitel) nincs szükség kormányzati engedélyre.

Az átalakuló önkormányzati rendszer egyik újdonsága, hogy az óvoda kivételével az általános iskolák, a kórházak járó- és fekvőbeteg-ellátása állami fenntartásba 
került, de az alapfokú egészségügyi ellátás maradt az önkormányzatoknál1․ Ettől a módosítástól azt várták, hogy az új struktúra költségtakarékos és feladatközpontú lesz, továbbá szigorúbb kereteket szab az önkormányzati autonómiának (Szabó 2012).

Az alapfokú oktatási intézmények fenntartásán túl az állam számos további feladatot is átvett az önkormányzatoktól. A kulturális feladatokat (mozik, színházak üzemeltetését) továbbra is az önkormányzatok látják el, ahogy a szociális ellátás is helyi kötelezettség maradt. Míg a megyei önkormányzatok fekvőbeteg-ellátási, szociális, oktatási és kulturális intézmény fenntartási feladatai az államhoz kerültek 2012től (2011. évi CLIV tv.).

A területfejlesztés törvényi kereteinek meghatározása, új intézményrendszerének kialakítása többlépcsős folyamat keretében valósult meg, melynek első lépcsőfokaként 2012. január 1-jén hatályba lépett a 1996. évi XXI. törvény (területfejlesztési törvény) módosítása. A területfejlesztéssel és területrendezéssel összefüggő egyes törvények módosításáról szóló 2011. évi CXCVIII. törvény szerint:

- a területfejlesztés intézményrendszerét jellemző, egymással versengő középszintú szervezetek problémája megoldódik;

- a megyei önkormányzatok feladatát képezi a területfejlesztés területi szinten;

- a területfejlesztési és területrendezési hatáskörök egy kézben összpontosulnak;

- az egyes tervek közötti összhang biztosíthatóvá válik;

- a járás szerveihez nem kerülnek területfejlesztési feladatok.

A megyei önkormányzatok szerepének újraszabályozásából az is kitúnik, hogy a kormányzat szerepe minden eddiginél fontosabb lett, erőteljesebb beleszólást kapott a települések és a megyék mindennapi ügyeibe. A megyéktől gyakorlatilag minden feladatot átvettek, de a megyei intézmények fenntartásánál is többet jelentett a megyék adósságának átvállalása (197,6 milliárd forint összegben). Átkerült az államhoz több települési feladat is, az általános iskolák és a kórházak, valamit a gyermekek szociális ellátása is (2011. CXC. és 2011. CLIV. tv., 258/2011. (XII.17.) Korm. rendelet, 72/2011. (XII.27.) NEFMI rendelet). Schlett tanulmányaiban (2016, 2017a) vizsgálta az önkormányzati rendszert és az államháztartást, kiemelten az önkormányzati feladatellátásra. A feladatátrendezés jelentős technikai hátteret és szakmai felkészültséget is igényelt.

A megyék szerepe ennek megfelelően alapvetően megváltozott, a korábbi intézményfenntartó szerepük megszűnt, az iskolákat, az egészségügyi és a szociális intézményeket, a korábban felhalmozott adóssággal együtt, valamint az ott dolgozó munkatársakat az állam vette át. A megyék pedig 2012-től alapvetően területfejlesz-

${ }^{1}$ A Nemzeti Köznevelésről szóló 2011. évi CXC. törvény lehetőséget biztosított, hogy 3 ezer fő alatti települések is vállalják az általános iskolák múködési feladatainak ellátását, amennyiben ezt anyagi helyzetük megengedi. Ezt szándéknyilatkozat formájában kellett megtenniük 2012. szeptember 30-ig, de a helyhatóságok döntő hányada nem élt a lehetőséggel.

Területi Statisztika, 2018, 58(6): 595-609; DOI: 10.15196/TS580603 
tési és területrendezési, vidékfejlesztési, valamint koordinációs feladatokat látnak el. Ennek megfelelően a megyei önkormányzat feladatainak ellátásában együttmúködik a települési önkormányzatokkal, a megye fejlesztésében közvetlenül és közvetve közremúködő területi államigazgatási szervekkel, az érdekelt civil és szakmai szervezetekkel. A megye területén összehangolja a kormányzat, az önkormányzatok és a gazdasági szervezetek fejlesztési elképzeléseit. Ennek keretében megvizsgálja és értékeli a megye társadalmi és gazdasági helyzetét, környezeti állapotát, adottságait. A vizsgálatok során felhasznált információkat és a vizsgálatok eredményeit a területi információs rendszer rendelkezésére bocsátja. A megyei jogú város önkormányzata bevonásával kidolgozza és elfogadja - az országos területfejlesztési koncepcióval összhangban - a megye hosszú távú területfejlesztési koncepcióját. Továbbá - a megyei területfejlesztési koncepció és területrendezési terv figyelembevételével a megye fejlesztési programját és az egyes alprogramokat. Előzetesen véleményezi a térségi területfejlesztési koncepciókat, területfejlesztési programokat, részt vesz az országos területfejlesztési koncepció és a nemzeti fejlesztési stratégia kidolgozásában. Szakmai kapacitásával segíti a területfejlesztési önkormányzati társulások és a térségi fejlesztési tanácsok tervező, döntés-előkészítő, fejlesztési célokat feltáró, pályázatokat megalapozó tevékenységeit (2013. évi CCXVI. törvény).

A megyei jogú városok szerepét hazánkban - történelmi elődeivel, a törvényhatósági jogú városokkal együtt - az határozza meg, ami egyrészt a nagyobb városok sajátos szabályozásával jár, másrészt a környék településeivel és az ott élő lakossággal kapcsolatos feladatokból adódik. Az önkormányzati rendszer jelenlegi átalakítása során, a feladatmegosztás új típusú rendszerében továbbra is fontos szerepet kapnak a megyei jogú városok. Ezeknek a nagyvárosoknak kiemelkedő gazdasági és társadalmi szerepük van, és egyben a közigazgatás központjai is az adott térségben. A városok magas tőkevonzó képessége következtében megtelepedett vállalkozások nemcsak a helyi lakosságnak, hanem a környező településeken élóknek is munkalehetőséget biztosítanak. Széles körű képzési, oktatási kínálattal, kulturális lehetőségekkel rendelkeznek, ami a megye, illetve a régió határán túl is vonzó lehet (KSH 2012). Schlett (2017b) azonban hangsúlyozza, hogy a közoktatási intézmények irányításához, fenntartásához széles körû együttmúködés szükséges a központi és a helyi szint között. Egy település gazdasági lehetőségeit, mozgásterét nagyban behatárolja, hogy a jogszabályokban megállapított állami támogatások, normatív hozzájárulások, valamint átengedett központi adók mellett mekkora saját bevételre tud szert tenni.

\section{Az önkormányzati eladósodás premisszái}

Az önkormányzati rendszert számos nehézség terhelte már a 2008-ban kitört válságot megelőzően is, amely részben megjelent a közfeladatok kormányzati alulfinanszírozásában, ugyanis 2005-től nominálértéken is csökkent az állami hozzájárulások

Területi Statisztika, 2018, 58(6): 595-609; DOI: 10.15196/TS580603 
mértéke. Schlett tanulmányaiban (2017a, 2017b) kitért arra, hogy a nagymértékú eladósodottság oka a feladat- és finanszírozási rendszer hibája volt.

\section{Az önkormányzati eladósodás folyamata és okai}

The process and causes of local government indebtedness

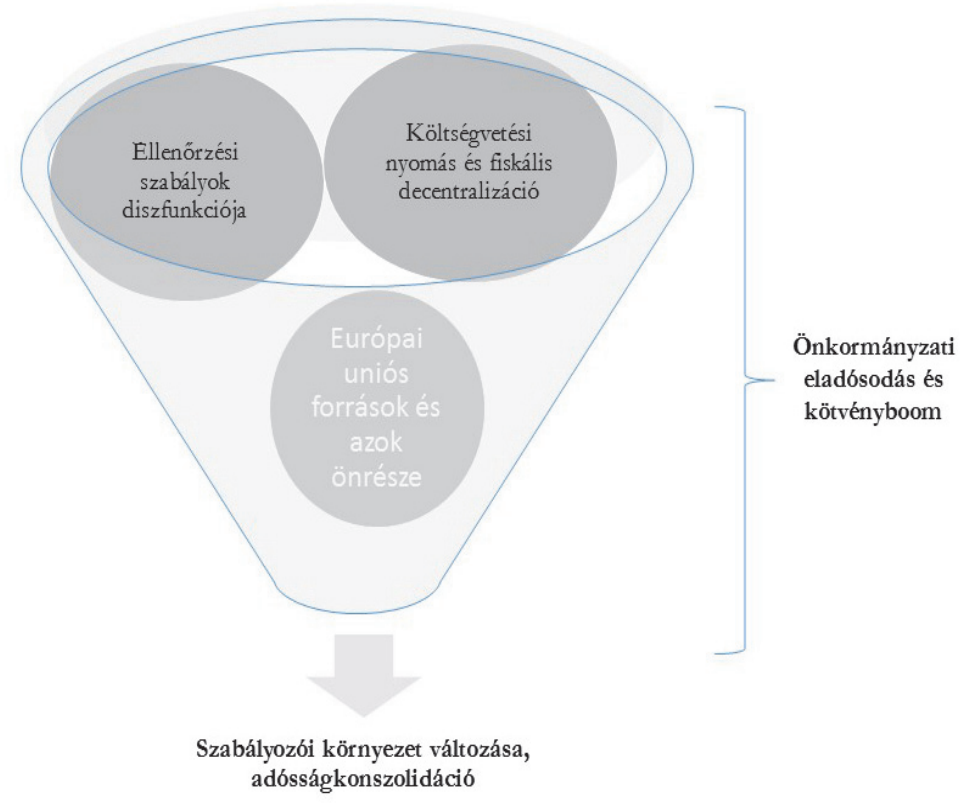

Az önkormányzatok számára bonitás és likviditáshiány mutatkozott, ezt elősegítette a számviteli rendszer pénzforgalmi elve is. A likviditás hiánya a szektorban a bevételek és a kiadások időbeli eltéréséból adódtak, különösen ott, ahol csekély volt a saját bevétel (Vigvári-Jánosy 2009).

Fábián (2016, 2017) és Csiszárik-Kocsir (2008a, 2008b) a válság hatását vizsgálta az önkormányzatokra. Fábián (2017) megállapítja, hogy a válság során a helyi önkormányzatok pénzeszközei a feladatuk ellátásához nem volt elegendó, így az adósságuk nagymértékben nőtt. Fábián (2016) tanulmányában megfogalmazta, hogy a decentralizáció megvalósulása már pedig a feladat- és hatáskör-telepítés mellett a feladatok elvégzéséhez szükséges erőforrások biztosítása. Csiszárik-Kocsir (2007, 2008a) megvizsgálta az önkormányzatok pénzügyi vagyonának összetevőit, rámutatott arra, hogy ha az önkormányzatoknak stabil adóbevétele lenne, akkor a válság hatására a külső forrásainak költsége nem változott volna.

A 2006-os konvergenciaprogram a költségvetési hiány leszorításának megoldását a nagy humán ellátórendszerek önkormányzati forrásból történő finanszírozásának hegemonizálásával biztosították, a megfelelő gazdasági feltételek teljesítését és módjait azonban nem ellenőrizték megfelelően, különösen a hitelfelvételi korlát betartását.

Területi Statisztika, 2018, 58(6): 595-609; DOI: 10.15196/TS580603 
Az eladósodási folyamatot szemlélteti a 2. ábra. Látható, hogy 2006-tól nagyfokú felfutás figyelhető meg, ennél kisebb ütemben, de a hosszú lejáratú hitelek állományának felépülése is kimutatható, a rövid lejáratú hitelek állományának minimálisra zsugorodása mellett.

\section{Az önkormányzatok külső forrásállománya}

External liabilities of the local governments

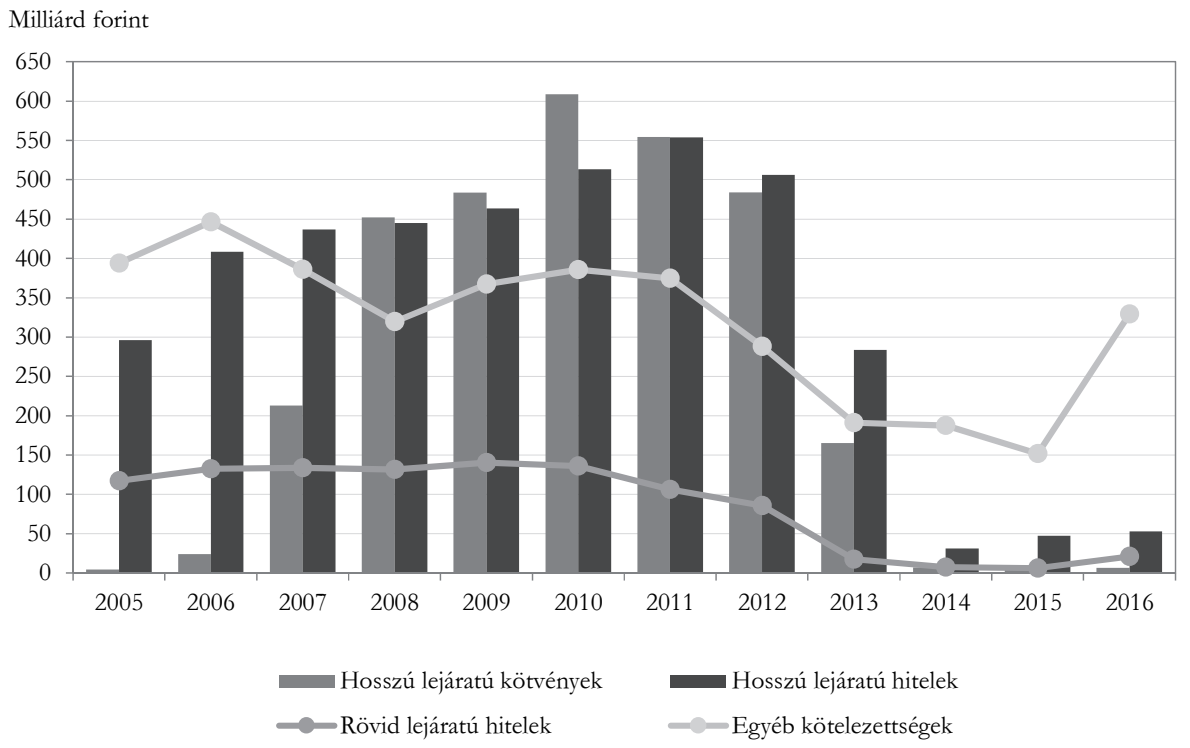

Forrás: MNB (2017) alapján saját szerkesztés.

Az említett múködési tényezők mellett 2006-tól kezdődően „kötvénykibocsátási boom" bontakozott ki a hazai helyhatóságoknál. Ezt jól jelzi, hogy 2006 és 2008 között 274 darab kötvénykibocsátás történt, amely főként a városi, megyei jogú városi és megyei önkormányzati szegmensben valósult meg, és a kötvénykibocsátások dinamikája csak 2010-re mérséklődött (Kovács 2007, Gál 2009, Csiszárik-Kocsir 2008a, 2008b, 2010).

Kovács-Csillik (2012) vizsgálta a hitelintézeti kitettségét az önkormányzati hitelállománynak, valamint a devizanemenkénti összetételét. Tanulmányukban megállapították, hogy az önkormányzatok teljes nettó pénzügyi vagyona 2010 után javult, a negatív tartományból pozitívba váltott. A kötvénykibocsátást mint pénzforrásban rejlő legfőbb motivációt elsősorban meglévő adósságok rendezése, illetve a 2007-ben kezdődő programozási időszak Európai Unió által társfinanszírozott forrásokhoz szükséges önerő biztosítása adta, az ÁSZ megállapításai alapján, ugyanakkor számos atipikus jellemzővel rendelkezett. Ennek egy jó indikátora, hogy nem

Területi Statisztika, 2018, 58(6): 595-609; DOI: 10.15196/TS580603 
alakult ki a kötvényeknek a másodlagos piaca, az értékpapírokat a számlavezetô bankok jegyezték le, amely így rejtett hitelfelvételnek minősíthető. Az önkormányzati kötvények útján történő forrásszerzés hátterében az volt, hogy a hitelfelvétellel szemben a kötvénykibocsátás nem volt közbeszerzési eljárás kötelezett, valamint a hitelfelvételi szabályozás szigorításának - utólag kiderült - alaptalan híresztelése húzódott meg. Atipikus jellemzôként értelmezhető az extrém hosszú futamidő, illetve az első néhány évben a tőketörlesztési moratórium, valamint devizában, zömében svájci frankban való denomináció (Gál 2009, Vigvári 2009). Az adósságállomány 50\%-ának nem volt felhalmozási célhoz kötött jellege, a közgazdasági logikával ellentétben, ráadásul 2009-ig csökkenő felhalmozási kiadási szint mellett valósult meg (Homolya-Szigel 2008).

Az önkormányzati rendszer múködési és felhalmozási költségvetésében és az átfogó gazdálkodásban nagymértékủ egyensúlytalanságok léptek fel, ebből adódóan a banki kitettség folyamatosan nőtt a munkabér- és a likviditási hitelszerződések folyamatos megújitása miatt. 2010. év végén a folyamatban lévő beruházások 1154 milliárd forintot kitevő jövőbeli kötelezettségállománnyal voltak terhelve, ezen túl a középszintű és a városi önkormányzatoknál még további 217 milliárd forintra volt igény. Jelentős probléma volt ezen kívül a múködési költségvetésben megjelenő szállítói finanszírozás, amelyet a helyhatóságok a külső finanszírozás eszközeinek tekintettek (Lentner 2014, 2015a).

\section{Az adósságkonszolidáció folyamata}

Adósságkonszolidációra a települési önkormányzatok között 5 lépésben került sor. 2011-ben a megyei önkormányzatok adósságállományát átvette az állam 198 milliárd forint értékben (3. táblázat).

\section{Az adósságkonszolidáció lépései}

3. táblázat

The process of debt consolidation

\begin{tabular}{c|l|c|c}
\hline Év & \multicolumn{1}{|c|}{ Érintett önkormányzati kör } & $\begin{array}{c}\text { Önkormány- } \\
\text { zatok száma }\end{array}$ & $\begin{array}{c}\text { Konszolidált } \\
\text { összeg, milliárd } \\
\text { forint }\end{array}$ \\
\hline 2011 & Megyei önkormányzatok és fövárosi önkormányzat & 20 & 198 \\
2012 & 5000 fö lakos alatti önkormányzatok I. ütem & 1700 & 74 \\
2013 & 5000 fő lakos alatti önkormányzatok II. ütem & 14 & 10 \\
2013 & 5000 fő lakos feletti önkormányzatok I. ütem & 305 & 685 \\
2014 & 5000 fő lakos feletti önkormányzatok II. ütem & 305 & 420 \\
\hline
\end{tabular}

Forrás: Gyirán (2016) alapján saját szerkesztés.

Területi Statisztika, 2018, 58(6): 595-609; DOI: 10.15196/TS580603 
A megyei önkormányzatok szerepe csupán az intézmények fenntartására korlátozódott, illetve nem volt érdemi saját bevételük a megyei önkormányzatoknak, az illetékbevételeket 2009-ben felerészben a központi szint elvonta, így az adósságátvállalás logikus lépés volt, amelyet az érintett vagyon átvétele is követett.

2012-ben az 5000 fő alatti települések adósságát vette át a központi költségvetés, 1700 településtől 74 milliárd forintot, az euró- és svájcifrank-alapú tartozások esetében fix árfolyamon, melyet 2012. december 28-án pénzügyileg rendeztek. Ennek során 5000 főnél kisebb települések adósságkonszolidációja során 1684 önkormányzat közel 50,5 milliárd forint hazai devizában denominált adósságát rendezték, ennek során 73 millió forint óvadéki betétet fizettek be a Magyar Államkincstár részére. A svájci frankban denominált adósság 97 önkormányzatot érintett, 103 hitelszerződés keretében 94 millió svájcifrank-alapú adósságot vállalt át a központi költségvetés. Ezen túl 13 önkormányzat 16 hitelszerződéséből adódó 835 millió forint értékú euróban denominált adósságot vettek át (Lentner 2014, 2015a, Gyirán 2016).

4. táblázat

\section{A konszolidált adósság devizanemenként}

Consolidated debt by currency

\begin{tabular}{c|c|c|c|c|c|c}
\hline \multirow{2}{*}{ Év } & \multicolumn{2}{|c|}{ Forintban } & \multicolumn{2}{c|}{ Svájci frankban } & \multicolumn{2}{c}{ Euróban } \\
\cline { 2 - 7 } & $\begin{array}{c}\text { milliárd } \\
\text { forint }\end{array}$ & $\begin{array}{c}\text { érintett } \\
\text { szerződés }\end{array}$ & $\begin{array}{c}\text { milliárd } \\
\text { forint }\end{array}$ & $\begin{array}{c}\text { érintett } \\
\text { szerződés }\end{array}$ & $\begin{array}{c}\text { milliárd } \\
\text { forint }\end{array}$ & $\begin{array}{c}\text { érintett } \\
\text { szerződés }\end{array}$ \\
\hline 2012 & 50,5 & 1684 & 22,428 & 103 & 0,835 & 16 \\
2013 & 334,5 & 1527 & 422,1 & 370 & 276,5 & 118 \\
\hline
\end{tabular}

Forrás: Lentner (2014) alapján saját szerkesztés.

A második lépésben a 2012. évi CCIV. törvény a 2013. évi központi költségvetés alapján a Magyar Állam átvállalta az 5000 fó lakosságszámot meghaladó települési önkormányzatok 2012. december 31-én fennálló adósságállományát és részben járulékainak összegét is. A részbeni átvállalást a település lakosságszáma és az iparűzési adón mért adóerő-képessége (2012-es félévi beszámoló, valamint a január 1-jei lakosságszám) határozta meg, figyelembe véve az adott településkategória korrigált átlagértékét. A hivatkozott költségvetési törvény ezek alapján 4 településkategóriát definiált. A településkategória átlagát a felső és alsó dekád elhagyásával érintett sokaság egyszerú számtani átlagával számolták ki. Ennek alapján, amennyiben a korrigált átlagot elérte vagy meghaladta a település adóerő-képessége, abban az esetben a helyhatóság adósságállományának 40\%-át érintette a konszolidáció, 75-100\% közötti adóerő-képesség esetében az adósság 50\%-át, 50-75\%-os adóerő-képesség esetében az adósság 60\%-át, $50 \%$ alatt a 70\%-át vállalta át az állam. A kategóriákhoz kapcsolódó adóerő-képesség átlaga 2012-es félévi beszámolók alapján az 5000 főnél nagyobb községeknél 13,3 ezer,

Területi Statisztika, 2018, 58(6): 595-609; DOI: 10.15196/TS580603 
5000 és 10000 fő közötti városok esetén 16 ezer, 10 000-fơnél nagyobb városoknál 23,5 ezer, míg a megyei jogú városok esetében 36 ezer forint volt egy főre vetítve. Ez számértékben kifejezve 305 önkormányzat 685 milliárd forint értékú adósságát érintette, amelyből 477,1 milliárd forint kötvényt váltottak be a 2014-es költségvetési törvény (2013. évi CCXXX. törvény) alapján. Az állam és az önkormányzatok között 2013. február 28-ig köttetett a megállapodás az átvállalás mértékéről (Lentner 2014, 2015a, Gyirán 2016).

A harmadik lépés bejelentésére 2013 őszén került sor, a maradék 420 milliárd forint adósságot vett át az állam, mivel a szakmai egyeztetések során a helyhatóságok 90\%-a nagyobb adósságátvállalást kért. 2014. február 28-ig a Kormány átvállalta a 2013. december 31-én fennálló adósságot, 420 milliárd forintot (Lentner 2014, 2015a, Gyirán 2016).

A szakirodalomban viták alakultak ki arról, hogy helyes lépés volt-e az önkormányzati konszolidáció. Kornai (2014) álláspontja szerint az önkormányzatokat nem kellett volna konszolidálni. Lentner (2014) álláspontja szerint szükséges lépés volt, hiszen a hibás feltevéseken alapuló gazdaságpolitikai kurzus és finanszírozási rendszer miatt következett be a helyhatóságok eladósodása. Gyirán (2013) már inkább arra vonatkozó kérdéseket vet fel, mely szerint inkább a helyzethez vezető okokat kellett volna megoldani. A saját véleményünk az, hogy az intézkedés szükséges rossz volt, amely nélkül nem lehetett volna megőrizni az önkormányzatok múködőképességét, és jelentôs lokális problémákat idézett volna elő egy-egy térségi funkciókat ellátó város csődje.

\section{Quo vadis? Avagy a konszolidáció utóélete}

Az önkormányzatok pénzügyi helyzetének fokmérője a jegybanki statisztikákban a nettó pénzügyi vagyon alakulása. A folyamat során jól kimutatható (3. ábra), hogy az aggregált kötelezettségek értéke 2010-ben és 2011-ben meghaladta az önkormányzatok pénzügyi vagyonát, amely a fenntarthatatlan állapotra utalt. Az adósságkonszolidáció során az önkormányzatok pénzügyi vagyona nagymértékben növekedett, közel duplájára emelkedett 2013-hoz képest, amely nominális értéken rekordméretűnek számított, hiszen korábban nem volt arra példa, hogy ekkora legyen a helyhatóságok kötelezettség nélküli pénzügyi vagyona. Az önkormányzati vagyon kötelezettség oldalát az egyéb, zömében szállítói tartozások teszik ki, valamint a hitelek értéke, előbbi 2016-ban 300 milliárd, utóbbi 80 milliárd forint volt.

Területi Statisztika, 2018, 58(6): 595-609; DOI: 10.15196/TS580603 


\section{Az önkormányzatok nettó pénzügyi vagyona}

Net financial assets of the local governments

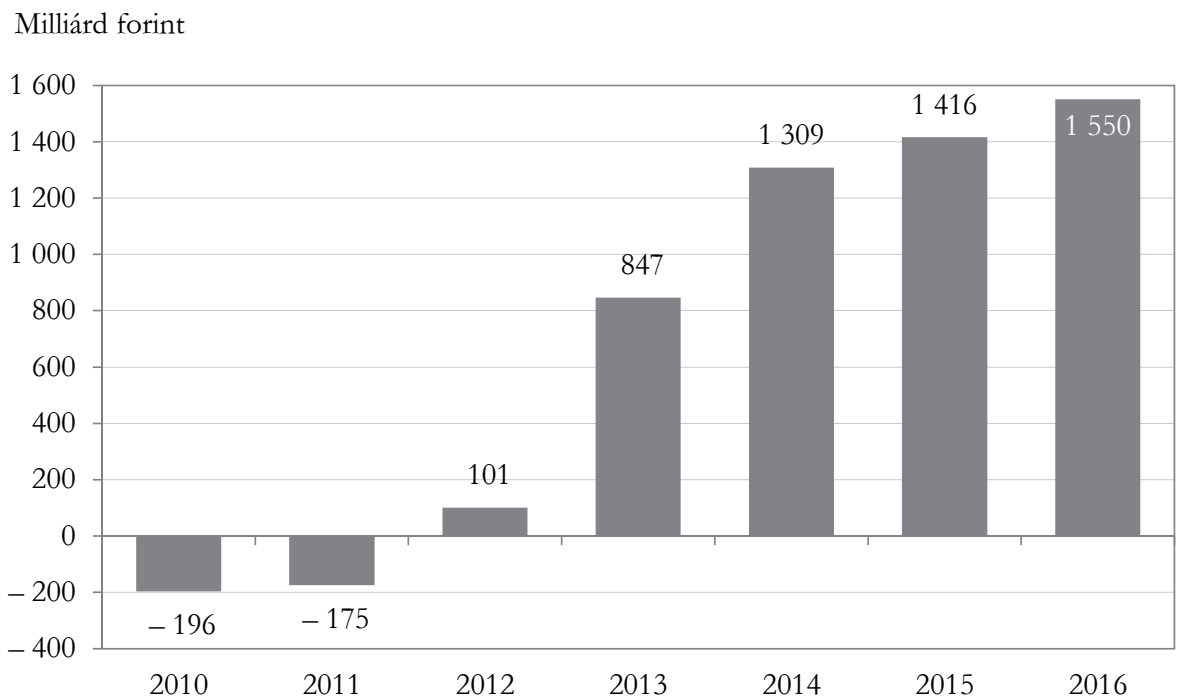

Forrás: MNB (2017).

Az önkormányzatok adósságuktól megszabadítva, mintegy „tabula rasa”-val kezdhették meg 2015-től a múködésüket. A helyhatóságok feladatellátási kötelezettségei a legnagyobb mértékben változtak meg a jelenlegi önkormányzati rendszer 1990-es genezise óta. A változást a profiltisztítás jellemzi, illetve számos feladat recentralizációján keresztül valósult meg, így a korábbi magyar önkormányzati struktúrából fenntarthatóbb feladatellátási keretek felé történt az elmozdulás (Lentner 2013, 2015b).

Fekete (2013, 2017a, b, c) vizsgálta a Modern Városok Program hatását a megyei jogú városok fejlesztéspolitikájára, a megyei jogú városok pénzügyi helyzetét, valamint ipari és térségi szervező szerepköreit, együttmúködési lehetőségeit. Megállapította, hogy új városfejlesztési eszközök léptek színre a 2014 és 2020 közötti európai uniós programozási időszakban. Ezen eszközök az integrált területi beruházás és a közösség által irányított helyi fejlesztés. Értékelte a Modern Városok Program szerepét a megyei jogú városi önkormányzatok fejlesztésének finanszírozásában, továbbá kitért a települések gazdasági helyzetét befolyásoló tényezőkre. Nemzetközi összehasonlító vizsgálat keretében tanulmányozta a vidéki nagyvárosok gazdasági kormányzással kapcsolatos tevékenységét. 
A szabályozás tehát az önkormányzat mind múködési, mind felhalmozási költségvetésére korlátozást gyakorol, ugyanakkor lehetőséget biztosít az önálló és rugalmas finanszírozás megteremtésére. A magyar szabályozás tehát a szigorúbb OECD-országok gyakorlatához került közelebb, a korábbi meglehetősen liberális szabályozással szemben (Sutherland 2005, Dafflon 2002).

A téma további kutatásokat igényel, különösen az, hogy a kisebb településeknél milyen hatása volt az adósságkonszolidációnak, milyen mértékben növelte a pénzügyi mozgásteret, valamint milyen hatással volt a feladat- és a hatásköri reform a települések gazdálkodására, valamint gazdaságára. Az önkormányzati gazdaság feszes gazdálkodásának lehetősége a szabályozási környezet megváltozásával és az adósságkonszolidációval alapozódott meg, azonban a múködőképességének fenntartásához nemcsak a helyi önkormányzatok megfelelő gazdálkodása, hanem a birtokukban lévő gazdasági társaságok stabil pénzügyi helyzete is szükséges feltétel (Zéman 2017 és Zéman-Tóth 2015).

\section{IRODALOM}

CsIsZÁRIK-Kocsir, Á. (2007): A területfejlesztés néhány időszerú dilemmája Gazdálkodás $51(1): 17-23$.

CSISZÁRIK-KOCSIR, Á. (2008a): Nem marad érintetlenül az önkormányzati szektor sem avagy a subprime válság hatásai a helyhatóságoknál Comitatus Önkormányzati Szemle 18 (11-12): 60-69.

CSISZÁRIK-KOCSIR, Á. (2008b): A magyar helyhatóságok eladósodása az ezredforduló után Tér és Társadalom 22 (4): 81-95. https://doi.org/10.17649/TET.22.4.1200

CsISZÁRIK-KoCSIR, Á. (2010): Az önkormányzati eladósodás jelene és jövője egy országos kvantitatív kutatás eredményei alapján Comitatus Önkormányzati S zemle 20 (7): 30-43.

DAFFlon, B. (ed.) (2002): Local Public Finance in Europe. Balancing the Budget and Controlling Dept Edward Elgar Cheltenham, Northampton (UK).

FÁBIÁN, A. (2016): A helyi önkormányzat (nem jogi) fogalmáról Új Magyar Kö̊rgazgatás (4): $35-40$.

FÁBIÁN, A. (2017): Local Self-Government in Hungary: The Impact of Crisis In: NunES SILVA, C.-BUČEK, J. (szerk.): Local Government and Urban Governance in Europe pp. 71-87. Springer International Publishing, Cham (Svájc).

FEKETE, D. (2013): Az EU regionális politikájának városfejlesztést támogató új eszközei a 2014-2020-as programozási időszakban: New tools for developing cities of EU regional policy in the period of 2014-2020 In: Rechnitzer, J.-Somlyódyné Pfeil, E.-Kovács, G. (szerk.): A bely szelleme - a területi fejlesztések lokális dimenziói pp. 145-154., A Fiatal Regionalisták VIII. Konferenciáján elhangzott előadások, Széchenyi István Egyetem Regionális- és Gazdaságtudományi Doktori Iskola, Győr.

FeKeTe, D. (2017a): A Modern Városok Program, elemzési lehetőségei Polgári Szemle 13 (1-3): 94-103

FEKETE, D. (2017b): Európai jármúipari térségek gazdasági kormányzási modelljei Tér és Társadalom 31 (3): 125-142. https://doi.org/10.17649/TET.31.3.2746

Területi Statisztika, 2018, 58(6): 595-609; DOI: 10.15196/TS580603 
FEKETE, D. (2017c): Felsőoktatási és Ipari Együttműködési Központ Győrben Polgári Szemle: Gazdasági és Társadalmi Folyóirat 13 (1-3): 106-115.

GÁL, E. (2009): Az önkormányzati szektort determináló kockázatok, és mérési lehetőségeik a hitelező szemszögéből Comitatus önkormányzati szemle 19 (5): 44-57.

GYIRÁN, Z. (2013): Az önkormányzati adósságrendezés kérdései In: HorVÁTH, M. T. Jelenségek - A városi kormányzás köréböl pp. 99-118., Dialóg Campus Kiadó, Budapest.

GYIRÁN, Z. (2016): Adósságkezelés, adósságrendezés az önkormányzati pén そügyekben Doktori értekezés, Debrecen.

Holczreiter, M.-SZÁmadó, R.-SZIlágyi, I.-TresZkáN-Horváth, V. (2015): Pályázatmenedzsment Nemzeti Közszolgálati Egyetem, Budapest.

Homolya, D.-SzIGEL, G. (2008): Önkormányzati hitelezés-kockázatok és banki viselkedés MNB szemle 2008/9: 20-29

KORNAI, J. (2014): A puba költségvetési korlát Kalligram Kiadó, Budapest.

KovÁcs, G. (2007): Azönkormányzati kötvénykibocsátások Magyarországon Doktori értekezés, Győr.

KovÁCs, L.-CSILLIK, P.(2012): Adatok és tendenciák az önkormányzati hitelezés területén Jegyzón és Körigazgatás 14 (3): 21-23.

KSH (2013): Megyei jogú városok. A főváros és a megyei jogú városok összehasonlító adatai, Budapest.

LENTNER, Cs. (2013): Köapénqügyek és állambáztartástan Nemzeti Közszolgálati és Tankönyv Kiadó Zrt., Budapest.

LENTNer, Cs. (2014):The Debt Consolidation of Hungarian Local Governments Pénzügyi Szemle 59 (3): 310-325.

LENTNER, Cs. (2015a): Önkormányzatok pénzügyi konszolidációja és múködőképes állapotban tartásuk eszközrendszere In: Lentner Cs. (szerk.) Adózási pénzü̈gtan és államháztartási gazdálkodás: Közpénzügyek és Allamháztartástan pp. 637-656., NKE Szolgáltató Kft., Budapest.

LENTNER, Cs. (2015b): A helyi önkormányzati rendszer egyes stratégiai kérdései - múlt és jövő In: KATONA, K.-KŐRÖSI, I. (szerk.): Felzárkózás vagy lemaradás?: A magyar gazdaság negyedszázaddal a rendszerváltás után pp. 31-48., Pázmány Press, Budapest.

LENTNER, CS. (2016): Rendszerváltás és pénzügypolitika: Tények és tévhitek a neoliberális piacgazdasági átmenetröl és a 2010 óta alkalmazott nem konvencionális es₹közökröl Akadémiai Kiadó, Budapest.

SCHLETT, A. (2016): Állambáztartás és szakpolitikák Pázmány Press, Budapest.

SCHLETT, A. (2017a): Közpénzügyi szemléletváltás: Elmozdulási irányok a gazdaságpolitika nagy elosztórendszereiben 2010 után Új magyar köæigazgatás 10 (Különszám): $29-41$.

SCHLETT, A. (2017b): Centralisation and decentralisation. Financing Public Education in Hungary International Journal of Arts and Sciences 10 (1): 383-389.

SUTHERLAND, D. (et.al. 2005): Fiscal rules for sub-central governments: design and impact OECD Economics Department Working Paper No. 465, Washington.

SZABÓ, L. (2012): Törvények a helyi önkormányzatokról - Összevetés 1990, 2011. Kodifikáció és közigazgatás 1 (1): 5-41.

Tiebout, CH. M. (1961): An Economic Theory of Fiscal Decentralization In: Public Finances: Needs, Sources, and Utilization pp. 79-96., Princeton University Press, Princeton.

Területi Statisztika, 2018, 58(6): 595-609; DOI: 10.15196/TS580603 
VÍGVÁRI, A. (2009): Atipikus önkormányzati eladósodás Magyarországon Közgazdasági Szemle 56 (7-8): 709-730.

VÍGVÁRI, A.-JÁNOSSY, D. (2009): Kockázatok az önkormányzati rendszerben ÁSZKUT, Budapest.

ZÉMAN, Z.-TÓTH, A. (2015): Az önkormányzatok és közüzemi vállalatok teljesítményértékelése In: LENTNER, Cs. (szerk.) Adózási pén ұügytan és állambáztartási gazdálkodás: Közpénzügyek és Állambáztartástan II. pp. 829-853., NKE Szolgáltató Kft., Budapest.

ZÉmAN, Z. (2017): The Risk-mitigating Role of Financial Controlling at Local Government Entities Modelling Profitability and Liquidity Aspects Public Finance Quarterly 2017/3: 294-309.

\section{INTERNETES HIVATKOZÁSOK}

ÁLLAMI SZÁMVEVŐSZÉK (2011): Összefoglaló a sajtó számára a megyék, a megyei jogú városok, valamint a föváros pénzügyi helyzete ellenôrzésének legfontosabb tanulságairól (letöltve: 2017.10.27.) http://www.aszhirportal.hu/documents/sajtoosszefoglalo-kozepszintpdf_20111116175057_70.pdf

KSH (2012): Megyei jogú városok KSH, Budapest. https://www.ksh.hu/docs/hun/xftp/ idoszaki/regiok/veszpremmjv10.pdf (letöltve: 2017.10.19.)

MNB (2017): Idósoros táblák sz̨ektoronként (SCV-kel)

https://www.mnb.hu/statisztika/statisztikai-adatok-informaciok/adatok-idosorok/xii-anemzetgazdasag-penzugyi-szamlai-penzugyi-eszkozok-es-kotelezettsegekallomanyai-es-tranzakcioi/teljes-koru-minden-szektorra-vonatkozo-penzugyiszamlak/idosoros-tablak-szektoronkent-scv-kel (letöltve: 2017. november 25.)

\section{HIVATKOZOTT JOGSZABÁLYOK}

Alaptörvény

2011. évi CLIV. törvény a megyei önkormányzatok konszolidációjáról, a megyei önkormányzati intézmények és a Fővárosi Önkormányzat egyes egészségügyi intézményeinek átvételéről

2011. évi CLXXXIX. törvény Magyarország helyi önkormányzatairól

2011. évi CXC. törvény a nemzeti köznevelésről

2011. évi CXCIV. törvény Magyarország gazdasági stabilitásáról

2013. évi CCXVI. törvény a területfejlesztésről és a területrendezésről szóló 1996. évi XXI. törvény módosításáról

258/2011. (XII. 7.) Korm. rendelet a megyei intézményfenntartó központokról, valamint a megyei önkormányzatok konszolidációjával, a megyei önkormányzati intézmények és a Fővárosi Önkormányzat egészségügyi intézményeinek átvételével öszszefüggő egyes kormányrendeletek módosításáról

1696/2014. (XI. 26.) Korm. határozat a 2014-2020-as programozási időszak országos jelentôségû közúti, vasúti és vízi közlekedési, városi és elővárosi közlekedési fejlesztéseinek indikatív

72/2011. (XII. 27.) NEFMI rendelet az állam tulajdonába és fenntartásába került egészségügyi intézmények tekintetében vagyonkezelői joggal rendelkező államigazgatási szerv kijelöléséről

Területi Statisztika, 2018, 58(6): 595-609; DOI: 10.15196/TS580603 